\title{
Beliefs and Practices Concerning Academic Writing Among Postgraduate Language- Teacher Trainees
}

\author{
CREENCIAS Y PRÁCTICAS SOBRE LA ESCRITURA ACADÉMICA ENTRE MAESTROS EN \\ FORMACIÓN EN POSGRADO \\ Croyances et PRATIQUeS D'ÉCRITURE CHEZ LES FUTURS ENSEIGNANTS EN CURSUS DU \\ DEUXIÈME CYCLE UNIVERSITAIRE
}

\author{
Carl Edlund Anderson \\ Ph. D. English, University of \\ Cambridge, Cambridge, U.K. \\ Assistant Professor, Department of \\ Foreign Languages and Cultures, \\ Universidad de La Sabana (Bogotá, \\ Colombia). \\ Campus del Puente del Común, Km. \\ 7, Autopista Norte de Bogotá. Chía, \\ Cundinamarca, Colombia. \\ carl.anderson@unisabana.edu.co \\ https://orcid. \\ org/0000-0001-8476-0434
}

\author{
Liliana Cuesta-Medina \\ Ph. D. English Philology, Faculty \\ of Humanities, UNED, Madrid. \\ Professor, Department of Foreign \\ Languages and Cultures, Universidad \\ de La Sabana (Bogotá, Colombia). \\ Campus del Puente del Común, Km. \\ 7, Autopista Norte de Bogotá. Chía, \\ Cundinamarca, Colombia. \\ liliana.cuesta@unisabana.edu.co \\ https://orcid. \\ org/0000-0002-8296-6225
}

\begin{abstract}
This paper reports on the initial stages of a larger study on plurilingual rhetorical communicative competences. Experiential evidence indicated a mismatch between the academic writing competences desired from and displayed by the participants-adult bilingual (L1 Spanish, L+ English) English-language teacher trainees in a postgraduate program at a Colombian university. We examined participants' beliefs and practices concerning academic writing to identify the sources of their challenges and develop the evidential basis for identifying appropriate remedial strategies. This was a mixed methods study, in which we analyzed data from semi-structured interviews, questionnaires, and student artifacts through the grounded theory approach and descriptive statistics. The results suggest that participants' challenges with rhetorical aspects of academic writing stem from a lack of training. However, participants were relatively successful with aspects of writing in which they had been trained: discrete language skills and purely descriptive prose. We conclude their academic writing difficulties are fundamentally non-linguistic and hypothesize they would face similar academic writing challenges even if writing in their L1. There is an urgent need to address these challenges, not only because rhetorical competences are increasingly important in a knowledge-driven society but also because teachers need to be able to train their own students in such competences.
\end{abstract}

Keywords: academic writing; English language; language teaching; teacher training; L2

\section{RESUMEN}

Este artículo expone las etapas iniciales de un estudio más extenso sobre competencias comunicativas retóricas plurilingües. La evidencia a partir de la experiencia mostró una disparidad entre las competencias en escritura académica deseadas y las que exhibía los participantes: adulto bilingüe (L1 español, L+ inglés) en formación para la enseñanza de lengua inglesa en un programa de posgrado de una universidad colombiana. Analizamos las creencias y prácticas de los participantes en relación con la escritura académica para identificar las causas de sus dificultades y desarrollar la base de evidencia para identificar las estrategias

Received: 2017-01-19 / Accepted: 2017-07-12 / Published: 2019-01-24

DOI: 10.17533/udea.ikala.v24n01a01 
correctivas apropiadas. Este fue un estudio de métodos mixtos, en el que analizamos datos procedentes de entrevistas semiestructuradas, cuestionarios y artefactos de estudiantes por medio del enfoque de la teoría fundamentada y la estadística descriptiva. Los resultados indican que las dificultades de los participantes en relación con aspectos retóricos de la escritura académica se derivan de la falta de capacitación. Sin embargo, los participantes mostraron un buen desempeño relativo en aspectos escriturales en los que se habían preparado: habilidades discretas del lenguaje y prosa puramente descriptiva. Se concluyó que sus dificultades que enfrentan en la escritura académica son fundamentalmente de carácter extralingüístico y se lanzó la hipótesis de que presentarían problemas similares en escritura académica en su primera lengua. Es urgente la necesidad de abordar estos problemas, no solo porque las competencias retóricas están cobrando cada vez mayor importancia en una sociedad orientada al conocimiento, sino también porque los docentes deben estar en capacidad de formar a sus estudiantes en dichas competencias.

Palabras claves: escritura académica; inglés; enseñanza de lenguas; formación de maestros; segunda lengua

\section{RESUMÉ}

Cet article présente les premières étapes d'une étude plus approfondie sur les compétences communicatives et discursives multilingues. Cette étude révèle un écart entre les compétences en écriture académique souhaitées par les participants et leurs pratiques. Etudiants titulaires d'une licence d'anglais, bilingues espagnol-anglais donc, ces participants suivent un programme de maitrise dans une université colombienne. Leurs croyances et pratiques d'écriture ont été analysées selon les critères d'une écriture académique afin $\mathrm{d}$ 'identifier les raisons de leurs difficultés et d'établir une base observable de ces aspects rédactionnels afin de développer des stratégies scripturales y remédiant. Suivant l'approche de la théorie fondée (grounded theory) et les statistiques descriptives, les méthodes adoptées mixtes ont permis d'analyser des entrevues semi-dirigées, des questionnaires et d'autres données des étudiants. Les résultats indiquent que les difficultés relatives aux aspects discursifs de l'écriture académique sont dues à un manque de formation. Néanmoins, après avoir été soumis à différentes pratiques scripturales, les participants montrent une certaine maitrise des aspects suivants: habilités discrètes du langage y rédaction de descriptions. En conclusion, on peut dire que les difficultés ne sont pas de caractère linguistique, ce qui nous invite à penser qu'ils présentent les mêmes difficultés rédactionnelles en langue maternelle. Il est donc nécessaire de palier à ces difficultés non seulement parce que les compétences discursives sont essentielles dans une société régie par les connaissances mais aussi parce que, en tant qu 'enseignants ils devront développer chez leurs étudiants ces compétences discursives à l'écrit.

Mots clés : écriture académique ; anglais ; enseignement de langues ; formation $\mathrm{d}$ 'enseignants; deuxième langue 


\section{Introduction}

This paper reports on results from the initial stages of a larger study on plurilingual rhetorical communication. The larger study is oriented towards identifying effective strategies for helping multi-/ plurilingual professional, scientific, and academic writers whose first language (L1) is not English learn to produce more effective argumentative texts in both English as an additional language $(\mathrm{L}+)$ and their L1. The needs-analysis stages, on which the present paper reports, had the objective of identifying the beliefs and practices concerning academic writing of adult bilingual (L1 Spanish, L+ English) in-service English-language teacher trainees in a postgraduate program at a private university in Colombia. In this paper, the term academic writing refers generally to the forms and styles of rhetorical prose used for research communication in various academic fields. Quality assurance processes within the program had, over a period of 5 years, captured reports of experiential evidence indicating a severe mismatch between the academic writing competences desired from language teacher trainees studying in the program-which were intended to reflect the kinds of professional writing competences required in their field-and the competences these students displayed in their written work. Although there were many aspects of trainee writing that revealed a need for improvement, one of the most salient problems was the difficulty many trainees had in producing effective argumentative writing: presenting a point of view on a topic and supporting it logically through the presentation and discussion of relevant evidence.

This situation was cause for concern for two principal reasons. Firstly, writing assignments are amongst the most significant aspects of evaluation within the program - as in much of contemporary Western academia. Within this tradition, argumentative writing is itself considered pedagogical: students are expected to construct their knowledge about a topic using higher-order thinking skills (Anderson et al., 2001; Bloom, Engelhard,
Furst, Hill, \& Krathwohl, 1956) employed in various writing assignments. Thus, problems with writing are often related to problems with learning. Secondly, given that the students under consideration were themselves teacher trainees - teachers with weak academic writing competences may well have trouble fostering the kinds of strong academic writing competences critical for the construction of knowledge in Western academic traditions in their own students.

\section{Commoditization of education and writing in the Anglophone world and Colombia}

Concerns about poor student writing have been commonplace worldwide amongst educators and journalistic commentators for generations. With regards to Anglophone, especially American, contexts, Grant (2010) notes that perceptions of a "writing crisis" amongst tertiary-level students in particular are often linked to larger, socially driven changes (see also Schroeder, 2001), such as those related to the entry of new, expanded populations into higher education (Berlin, 1984, 1987; Douglas, 1976; T. P. Miller, 1997) or to technological changes that alter the ways written texts are conceived, produced, and consumed (Eisenstein, 1979; C. R. Miller \& Shepherd, 2004). Not surprisingly, then, the recognition of a need for specialized academic writing instruction in the Anglophone world dates from the later $19^{\text {th }}$ century, when-much as in Colombia at present-changing social, economic, and technological conditions were linked to concomitant changes in education, especially at the tertiary level. Anglophone universities of the later $19^{\text {th }}$ century were simultaneously incorporating a larger and more diverse body of students and placing a new emphasis on research and the diffusion of knowledge generated from research (Russell, 2002). However, Grant (2010) also argues that, during the same period, the focus of higher education began to shift away from a "liberal arts" model (Pascarella, Wolniak, Seifert, Cruce, \& Blaich, 2005) and towards a more "general" even "vocational” model (Grant, 2010, Defining 
Liberal Arts section, para. 3) . Moreover, Grant (2010) likewise argues that the understanding of writing in education also changed, from that of a fundamentally rhetorical endeavor (that is, one intended to produce a persuasive effect on its audience) to an essentially mechanical activity, focused on grammar and style, in which writing instruction became divorced "from any sense of purpose, audience, or higher reasoning skills." From the last decades of the $20^{\text {th }}$ century, there has been some new interest in rhetorical writing in the Englishspeaking world, though pressures generated by the increasing commoditization of education continually push the emphasis back towards mechanics, summarization, and regurgitation.

In recent decades, social and economic developments comparable to those that affected education and writing instruction in later $19^{\text {th }}$ century Anglophone universities (Grant, 2010) have also been transforming Colombia. Yet though there is reasonably extensive literature on L1 (Spanish-language) academic-writing instruction in Colombia (Arias Arias \& Agudelo Montoya, 2010; Colmenares, 2013; Goyes Morán \& Klein, 2012; Lora González, 2010; Narváez Cardona et al., 2009; Rincón \& Gil, 2010), it is difficult to uncover, even from the larger surveys (Camargo Martínez, Uribe Álvarez, Caro Lopera, \& Castrillón, 2008; González Pinzón \& Vega, 2013; Laco, Natale, \& Ávila, 2010; Moya Pardo, Vanegas Sánchez, \& González González, 2014; Ortiz Casallas, 2011; Pérez Abril \& Rincón Bonilla, 2013), a historical perspective that goes further back than the late $20^{\text {th }}$ century. This may be because of the relatively limited population that participated in Colombian tertiary education, where academic writing demands are most salient, until relatively recently (Bushnell \& Hudson, 2010).

As societies worldwide become increasingly integrated, and it is increasingly the "knowledge society/economy" (Armstrong, 2001; Carlaw, Oxley, Walker, Thorns, \& Nuth, 2006; Cowan \& van de Paal, 2000; David \& Foray, 2002; Drucker,
1992; Hall \& Mairesse, 2006) in which current learners can expect to act out their personal and professional lives, education and education systems must adapt appropriately-and quickly. Many leading education researchers and theorists agree that education systems must prepare learners with the capacities to think critically, solve problems, and make arguments (Ripley, 2013; Sahlberg, 2011, 2014; Wagner, 2008, 2012); we would add that an ability to perform these capacities through multiple languages is also increasingly important. All these capacities are interrelated, though the present study focuses on argumentation (Johnson, 2000; Toulmin, 2003), which is understood as fulfilling a critical pedagogical, knowledge-creating role (MacDonald, 1994; Scott, 1967), and particularly on written argumentative texts of the type required for success in academic and professional contexts.

\section{Previous work on L2 academic and rhetorical writing}

In recent decades, the English language has increasingly been recognized as a critical academic lingua franca. Leaving aside ideological concerns about linguistic hegemony (Hyland, 2016), the simple preeminence of English at present in academic, scientific, technological, and research publishing (Graddol, 1997) points to the potential advantages available to those who can access knowledge and participate in ongoing debate and through that language. However, numerous authors have addressed the challenges that academic writing published in English poses for students and researchers working with English as an L+ (Ammon, 2007; Benfield, 2006; BurroughBoenisch, 2006; Casanave, 2008; Coffin et al., 2003; Curry, 2011; Curry \& Lillis, 2004; Flowerdew, 2008, 2009; Kaplan \& Baldauf, 2005; Lillis \& Curry, 2006; Uzuner, 2008), including affective issues such as self-efficacy (Huerta, Goodson, Beigi, \& Chlup, 2016) and self-regulated learning (Cuesta Medina \& Anderson, 2014; Hammann, 2005). 
Much previous work on academic writing amongst L2 English speakers has been performed in Anglophone university contexts, though there has been an increasing emphasis on both L2 academic writing in the writers' own L1 contexts. Many such studies consider Asian (Chazal \& Aldous, 2006; Evans \& Green, 2007; Flowerdew, 1999a, 1999b; Li \& Flowerdew, 2009; Liu, 2005; Riazi, 1997) or European (Bardi, 2015; Bennett, 2010a, 2010b; Björk, Bräuer, Rienecker, \& Jörgensen, 2003; Duszak \& Lewkowicz, 2008; Ferguson, PérezLlantada, \& Plo, 2011; Fernández Polo \& Cal Varela, 2009; Johns, 2003; Lillis \& Curry, 2006, 2010; Muresan \& Pérez-Llantada, 2014; PérezLlantada, Plo, \& Ferguson, 2011) contexts.

Latin American contexts have probably received less attention in the international sphere (but, for example, Hanauer \& Englander, 2011), though national journals increasingly cover such topics. In the case of Colombia, various studies have treated topics related to argumentative and/or academic writing in English as an L+ (Cárdenas, 2003, 2014; Castañeda, 2012; Chala Bejarano \& Chapetón, 2013; Correa, 2010; Crawford, Mora Pablo, Lengelign, \& Goodwin, 2013; Escobar Alméciga \& Evans, 2014; Gómez, 2011; Janssen, Nausa, \& Rico, 2012; Nanwani, 2009; Viáfara Gozález, 2008). These, however, have not specifically considered the nature of prior training in writing, especially academic writing, in either the $\mathrm{L} 1$ or an $\mathrm{L}+$, though some work on Spanish non-native English speaking (NNES) academic writers has emphasized issues of insufficient training (Burgess \& MartínMartín, 2008; Gea-Valor, Rey-Rocha, \& Moreno, 2014; López-Navarro, Moreno, Quintanilla, \& Rey-Rocha, 2015; Moreno, Rey-Rocha, Burgess, López-Navarro, \& Sachdev, 2012).

Similarly, few Colombian studies have focused on perceptions and beliefs about academic writing (though see Cárdenas, 2014), as have various international studies, considering both writing instructors and NNES writers (Casanave \& Hubbard, 1992; Diab, 2005; Díaz Hormazábal,
2007; Hammann, 2005; Huang, 2010; Jenkins, Jordan, \& Weiland, 1993; Leki, 1994; Matsuda, Saenkhum, \& Accardi, 2013; Pérez-Llantada et al., 2011; Pittam, Elander, Lusher, Fox, \& Payne, 2009; Shi \& Cumming, 1995; Wan, 2014; Yildirim \& Ilin, 2009). However, most of these have considered the cases of writers already immersed in training programs for academic writing or who at least have become aware of the need for such training due to professional demands.

\section{Research objective and questions}

Accordingly, with the objective of contributing to a more systematic identification of the sources of this population's apparent difficulties with academic writing to then provide an evidential foundation for further work oriented towards identifying more effective strategies for training in academic writing, the present study was guided by research questions asking the following:

- What prior training on writing, especially academic writing, did adult bilingual (L1 Spanish, L+English) in-service English-language teacher trainees experience before entering a postgraduate program at a private university in Colombia?

- What are the beliefs and practices of the adult bilingual (L1 Spanish, L+ English) in-service English-language teacher trainees beginning a postgraduate program at a private university in Colombia regarding academic writing in both their $\mathrm{L} 1$ and $\mathrm{L}+$ before they receive any training through the program in which they enrolled?

\section{Methodology}

\section{Study design and sample}

This was a mixed-method study which made use of two data integration strategies: sequential exploratory strategy and sequential explanatory strategy (Creswell, 2012; Creswell \& Plano Clark, 
2011). The study started with a mixed-method phase to identify preliminary results. Then, these results were followed-up with an in-depth qualitative phase to assess why these results might have occurred.

There were 56 participants aged 25-40 (mean age 29.76), divided into five groups, drawn from two master's programs for in-service English-language teachers at a private university in Colombia, South America. All the participants held undergraduate or professional degrees. The researchers contacted 80 students from the programs' student population for potential participation in the study, and invitations were made face-to-face and/or by e-mail. Ultimately, 56 students voluntarily consented to participate in the study.

\section{Data collection instruments and procedures}

Procedures followed in this study complied with all the appropriate ethical concerns of a research structured interviews and questionnaires, as well as student artifacts. The questionnaire (see Appendix A) was designed by the researchers to provide information about the participants' experience, training, and current understanding of academic writing practices. It also inquired about their conceptualization of the genre and its perceived features, the strategies and resources used, and the difficulties they might have experienced when writing academic texts. After piloting to review its validity and reliability, the questionnaire was distributed via the web-based Google Docs service (http://docs.google.com/). As a follow-up to the questionnaire, to expand understanding of the phenomena under investigation, three 20-minute focus groups and 15 semi-structured interviews (each lasting 20-25 minutes) were held with selected participants. Questions guiding the focus groups and semi-structured interviews (see Appendix B) were designed by the researchers to elicit responses on topics of interest derived from analysis of the questionnaire responses; questions were validated prior to

implementation. In particular, participants were asked about actions taken and processes followed when they produced academic texts, the perceived effectiveness of them, and whether they perceived any need to improve on their current levels of competence. Focus groups and interviews were held either on the participating university campus or through Skype; interviews were held individually, while focus groups consisted of 3 participants in each instance.

Student artifacts (56) were collected throughout three academic semesters and assessed by the program instructors against the task requirements specified in the participants' program documentation; this documentation could be shared upon request with interested researchers. Additionally, a total of 34 participant posts produced in online course forums during the introductory phase of the participants' research courses were taken into consideration to expand the data on their beliefs and practices regarding academic writing prior to the commencement of instruction on this topic as part of their regular program of study.

\section{Data analysis procedures}

To identify the underlying causes of the participants' academic writing difficulties, qualitative data from questionnaires, interviews and focus groups, and student artifacts (ranging from forum posts, to short essays or term papers prepared as coursework, to thesis-length research reports) were triangulated, coded, and analyzed using the grounded theory approach to consolidate main themes and categories that responded efficiently to the study's inquiry (Corbin \& Strauss, 2008). Extracts from the analyzed data relevant to answering the present study's research questions are presented in the Results section. Additionally, the questionnaires yielded some basic quantitative data that was analyzed through frequency counts and simple descriptive statistics (Chambliss \& Schutt, 2012). In all cases, participant identities have been anonymized. Illustrative examples from the analyzed data presented in the Results section 
are identified with the capital letter " $\mathrm{P}$ " plus either a letter (for interview responses; for example, "PM," for "Participant M") or number (for questionnaire responses or other examples from artifacts; for example, "P1" for "Participant 1").

\section{Results}

\section{Results concerning participants' prior training in writing}

Most (52 out of 56) of the participants claimed to have received some kind of prior training on writing in their L+ (English), all within the context of undergraduate degree programs. However, most concurred that this training was general, not focused on academic writing as such: descriptors such as "traditional," "general," and "superficial" recurred often in the data.

- Training in English requires the same model in order to learn the important concepts. (Questionnaire, P44)

- Very different, I have gone deeper in my L1 for obvious reasons, I am a good writer of Spanish, but not so good at English. L2 writing training was too short and superficial. (Questionnaire, $\mathrm{P} 49$ )

- I think the training I received in Spanish, my L1, was mainly based on the right use of vocabulary. Aspects such as structuring a paragraph or linking ideas were disregarded. (Questionnaire, P27)

Additionally, less than half of the participants ( 26 out of 56) claimed to have received any kind of prior training on academic writing in their L1 (Spanish). However, it was always the case that any prior training had been part of some more general writing instruction in which the focus had been on mechanical aspects, for example, orthography and grammar. No participant had received discrete training focused specifically on academic writing in their L1. Some students (14 out of 56) claimed that their experiences teaching English as an $\mathrm{L}+$ had provided them with opportunities to improve their academic writing abilities, though it is difficult to say whether such perceptions were born out in reality.

- Probably, I have received more specific training in English writing than in Spanish. or [sic] at least, I can recall easier such training. Probably the fact that I teach students writing in my classes, makes me more aware of English writing. (Questionnaire, P26)

- Spanish writing wasn't focused on the correct structures to use, as it is done in English, but it was about taking out your ideas and stamp them on the paper. A matter of writing fluency. (Questionnaire, P28)

Some (10) students even reported feeling more comfortable with academic writing in the $\mathrm{L}+$ than in the L1, though the evidence also suggests that the postgraduate program in which the participants were enrolled placed a far greater emphasis on academic writing (all in the $\mathrm{L}+$ ) than had ever been demanded of them in any previous educational experience through either their L1 or L+.

- It's always been a challenge because I know I have to put a tremendous amount of effort to concentrate, write well and produce good paragraphs in my essays and reports. I thought I was good in writing because I never had any problem in Spanish. When it came to write to English, all was a disaster. (Interview, PB)

- I never imagine academic writing as that hard. I have to write too much, and sometimes I feel overwhelmed because the many papers I have in my to-do list. I have to recognize I do not have yet what I need to produce a good report. (Interview, PM)

\section{Results concerning participants' beliefs and practices about academic writing}

\section{Beliefs that goals and practices for academic writing are different in the $L 1$ and $L+$}

Thirty-nine (39) students held what we identified as grave misconceptions (implicit or explicit) about academic writing in general, for example, that appropriate rhetorical strategies for 
academic writing in the $\mathrm{L} 1$ and $\mathrm{L}+$ were completely different.

- Something I am learning how to deal with -this [sic] is something that differs from Spanish to English - is the sentence length. I have had many difficulties with this aspect and I think it is crucial to work on it to have a better performance in any writing context. (Questionnaire, P30)

- I think English is a lineal language while Spanish has a spiral way, on the other hand punctuation is a major difference between L1 and L2 because in English you are more punctual and in Spanish you have to organize more ideas to give a final conclusion or statement. (Questionnaire, P29)

\section{Beliefs that mechanical aspects of writing should be prioritized}

Interestingly — and somewhat alarmingly — when participants were presented with a list of seven features of academic writing (see Appendix A, Question 20) and asked to identify what they considered the most important of these features, by far the most frequent choice (21 out of 56 participants) for the most important feature was correct grammar. Other choices for the most important feature of academic writing received far fewer votes: the second most frequent choice was paragraph structure ( 8 out of 56 participants), the third was sentence structure (7 out of 56 participants), and the fourth was correct orthography (7 participants). Nevertheless, it is remarkable that these four most frequent selections for the most important element of academic writing tend to be focused on highly mechanical aspects of writing. The sixth most frequent choice was essay structure ( 5 out of 56 participants), and-very tellinglythe fewest votes for most important feature were split between evidence and persuasiveness, tied for last place with each receiving only 4 of the 56 votes. This strong perception bias towards a mechanical, non-rhetorical concept of academic writing is likewise reflected in participants' additional observations.
- "I think grammar is fundamental if you want to make you [sic] writing understandable and depend on your topic, evidence is so important to make your writing clear and objective." (Questionnaire, P29)

- "Because in order to write clear information, orthography and grammar must be written perfectly." (Questionnaire, P25)

- "They [orthography and grammar] are the basics when making use of the language specially for academic purposes, taking into account the type of readers that are going to get through the texts". (Questionnaire, P6)

Fifteen (15) participants also identified other recurring factors that they felt hindered development of their academic writing competences, including the misuse of translation, faulty drafting and outlining skills, lack of knowledge of "necessary" academic jargon, and poor rhetorical skills.

- Translation, or think in L1 first in order to translate the idea to L2. (Questionnaire, P25)

- Probably, the most difficult part is to decide whether to paraphrase or cite literal ideas. Depending on the complexity of the text, sometimes one option is better than the other. To decide such thing, sometimes causes me trouble. Also, organizing ideas to avoid redundancy and repetition can be a pain in the neck. (Questionnaire, P26)

- Being direct is very hard for me as a Spanish speaker because we tend to give too many details or to beat around the bush. (Questionnaire, P27)

- I think the vocabulary I use most of the times, is no the expected in an academic writing but I find very difficult to synthetize some of my ideas and thoughts. (Questionnaire, P29)

- I think I lack essential vocabulary to write in an academic context and it usually takes really long for me to create a more elaborated sentence or paragraph. I (also) have to write reports for my supervisor and boss and I have been told that the sentences I write are too long (like the ones I produce in Spanish) and the ideas become ambiguous in some cases. (Questionnaire, P30) 


\section{Absence of rhetorical considerations from beliefs and practices}

However, considering the objectives of this study, the major problem encountered in the student artifacts analyzed was barely reflected in the participants' own concerns: poor argumentative competences. One of the few examples from the data of a student touching on this concern is presented in the following excerpt:

My greatest fear-mm-hmm-is to write well, following the models the instructor gives us, and produce what she calls arguments...the thesis are hard to produce because you need to come up with a good idea, and then find a way to support it with other tools. (Interview, PZ)

As recognized by this participant, grappling with the need to use evidence to support a particular point of view was a struggle for many. In many artifacts analyzed, participants simply failed to even express their own points of view, even when explicitly instructed to do so, preferring to summarize those of others found in their reading. The following excerpt (Draft 03, p. 32, P1), drawn from a participant's work for what was assigned as an analytical literature review (to identify a gap in research on/knowledge about a given topic in applied linguistics) is representative.

To conclude with studies carried at international level, Tinsley (n. d.) researched on cultural diversity and cross-cultural communication in children at NJ department of education. The researcher implemented classroom activities, that involved readings, video clips exposure and role plays, similar to the present research study. The researcher concluded that through the videos exposure the teachers learned about their students' culture, background and interests, as well as the students had the opportunity to develop some tasks as discussions that enabled them to make personal connections using a project-based approach. (Draft 03, p. 32, P1)

Despite somewhat awkward style, as might be expected of novice writers, the prose is perfectly comprehensible, yet has no real relationship with assigned task objectives. It is almost purely descriptive, with no critical analysis of, or argument about, the topic; no new ideas are developed, nor has the participant drawn any relationship between the topic they are summarizing and any other information or idea. When participants did try to promote a particular point of view, they almost invariably did so by expressing personal opinion with emphasis on the strength of their convictions (for example, through statements like "I strongly believe that...") rather than through evidence-based argument, even when they had carefully summarized, elsewhere in their work, evidence that they could have used. To be fair, to judge from the strident recommendation of the numerous instructional books published as guides to academic writing (for example, Biggam, 2008, pp. 64-68), such problems are extremely common amongst many beginning academic writers using either an L1 or L+. Yet, considering that the participants were part-time adult learners with numerous challenges in work and everyday life to produce additional concerns for them, the total cognitive load demanded to unlearn the belief that the learner's job is principally one of regurgitating pre-existing information in partially digested form - which they are otherwise in danger of transmitting to their own students-is considerable.

\section{Discussion}

\section{Participants' prior training in writing}

As noted in the literature review (see the Previous Work on L2 Academic and Rhetorical Writing section of the present study), most studies on beliefs and practices of university-level writers, either in Colombia or elsewhere, are conducted within the context of university writing courses that are, of course, intended to alter those beliefs and practices. Yet university students are not tabulae rasae: they enter university equipped with the technology of writing and must inevitably have acquired certain beliefs and practices in relation to it. While there is much anecdotal information from university faculty about what these beliefs 
and practices might be, few studies-especially in Colombia-have specifically considered them (see the Previous Work on L2 Academic and Rhetorical Writing section of the present study). Thus, our results represent a step towards developing a better picture of this issue.

Given that the participants in the present study were beginning postgraduate students, our results suggest that what they learned about writing in both their primary/secondary and undergraduate educations had helped them become relatively successful with aspects of writing (in either L1 or $\mathrm{L}+$ ) in which they had already been trained, these having been overwhelmingly concerned with grammar, orthography, and the production of accurate descriptive written prose. This finding lends further weight to the understanding that their problems are indeed not fundamentally linguistic, though many of the participants assumed that they were, and not the result of a complete lack of training per se. Rather, it seems that such training as they received simply did not include any effective focus on the rhetorical aspects of academic communication necessary for success at the university level.

\section{Participant beliefs and practices about academic writing}

In general, our results indicate that participants conceived of writing (generally) as an activity essentially for reporting information. This is a belief at odds with the fundamentally rhetorical focus of Western academic writing, as well as the conception of its production as a process (and, indeed, in educational settings, a process that is essentially pedagogical rather than informational) (Badger \& White, 2000; Flower \& Hayes, 1981; Freedman, Dyson, Flower, \& Chafe, 1987; Seow, 2002). Here again we interpret the participants' challenges with these aspects of academic writing as the result of prior training that lacked any effective focus on rhetorical aspects of academic communication. This lends additional support to the notion that their challenges with writing in the $\mathrm{L}+$ are not fundamentally the result of lacking appropriate linguistic skills in the $\mathrm{L}+$, as many participants themselves believed.

Indeed, participants' world-views largely lacked an understanding that effective academic writing in either their L1 or their L+ has a principally rhetorical objective. This puts them fundamentally at odds with not only their instructors but evaluators and the global research community as a whole, in whose own world-views such understandings occupy a central place (Casanave \& Hubbard, 1992; Cooper \& Bikowski, 2007; Kaufhold, 2015; Leki, 1994; Viáfara González, 2008; Yildirim \& Ilin, 2009). In other words, the problems that the participants had with regards to the writing tasks assigned by their instructors resulted principally from a clash of culturesthough given that the participants are implicitly seeking access and admission to the "alien culture" of academia, success in this endeavor implies that they must learn its ways. Nevertheless, the main challenge here may be that neither students nor many instructors recognize that such problems are indeed fundamentally cultural rather than linguistic.

\section{Effects of prior training in language and writing and current beliefs and practices}

The participants' overwhelming focus on mechanical aspects of written communication at the expense of rhetorical aspects may be the result of overemphasis on mechanical aspects in the writing instruction they themselves received in primary, secondary, and even tertiary educational contexts in both the $\mathrm{L} 1$ and the $\mathrm{L}+$. Indeed, the participants' own roles as teachers of an additional language may be exacerbating the problem. Operative here may be the "law of the instrument" (Kaplan, 1964, p. 28), famously formulated by Maslow (1966) as: "It is tempting, if the only tool you have is a hammer, to treat everything as if it were a nail" (p. 15). We have interpreted the participants' beliefs about writing and language as creating a domino effect with cascading negative 
outcomes, as they struggled to comprehend the academic challenges they faced armed only with tools that were insufficient for understanding the new, rhetorical demands of these challenges.

Cummins, in various publications (Cummins, 2008; Cummins, Brown, \& Sayers, 2007; Cummins \& Man Yee-fun, 2007), has drawn attention to the distinction between discrete language skills, the "rule-governed aspects of language (including phonology, grammar, and spelling)" (Cummins \& Man Yee-fun, 2007, p. 800) and cognitive academic language proficiency (CALP), the "ability to understand and express $[. .$.$] concepts and ideas$ that are relevant to success in school" (Cummins \& Man Yee-fun, 2007, p. 801), which certainly incorporate the concept of academic writing used in this study. Yet even in the present age of communicative language teaching, much classroom practice still focuses on just such discrete, or mechanical, aspects of language. Contemporary approaches to language teaching still tend to simplistically divide communicative competence into the infamous four skills of speaking, listening, reading, and writing (where classroom emphasis is, moreover, placed very much in that order; Hinkel, 2007). Despite recognition in the research literature that it is necessary to integrate discrete language skills into the classroom by connecting them to real world uses with functional goals (e.g., Nunan, 1989, 2001), the "four skills" scheme implicitly deemphasizes the varying purposes to which such skills might be put or the strategies that might be needed to achieve those purposes using one or more of those skills. In other words, this understanding of writing as a monolithic skill characterized by a focus on the discrete, mechanical (as opposed to cognitive-communicative) aspects of language has de-emphasized the critical roles played by audience and genre awarenessand, indeed, rhetorical purpose-needed for the development of effective communication, especially in academic and business contexts. In short, the participants seemed to approach what are fundamentally non-linguistic cognitive-communicative problems as if they were discrete language problems, because that is what their experiences, as both students and teachers of language, have prepared them to do.

These results are cause for concern, not merely because the argumentative professional communicative competences exemplified in academic writing are critical for success in an increasing number of $21^{\text {st }}$-century spheres, but because it is additionally important that teachers be able to train their own students in such competences.

\section{Recommendations for training in academic writing}

The growing need for tertiary students around the world to both access and produce academic works in English means it is well past time for educators and researchers outside the Anglophone sphereperhaps especially in the "developing world"-to look more seriously at strategies for developing their learners' academic writing competences in both the L1 and L+ (which is often English). Yet while it seems clear that training in plurilingual rhetorical communication should certainly not be restricted to bare linguistic competences (in L1 and/or L+), it should be emphasized that it also needs to go beyond formal rhetorical competences (important though they are) to take in not only genre and disciplinary awareness (Kuteeva $\&$ Negretti, 2016; Negretti \& Kuteeva, 2011; PérezLlantada, 2015) but also essential life skills, such as self-efficacy and self-regulation (Cuesta Medina \& Anderson, 2014; Hammann, 2005; Huerta et al., 2016). Moreover, accepting the premise that one of the chief goals of contemporary education should be to develop learners' argumentative competences (Ripley, 2013; Sahlberg, 2011, 2014; Wagner, 2008, 2012), we would also agree with those who argue such competences should be addressed from the primary levels (Anderson, McDougald, \& Cuesta Medina, 2015; Gárate \& Melero, 2005; Hillocks, 2011; Migdalek, Rosemberg, \& Yáñez, 2014; Mora González, 2014) and continued throughout learners' subsequent schooling. Of course, implementing such 
training requires teachers who are themselves well-versed in rhetorical communication.

Developing both remedial programs for current older learners, as well as preventative preparation for current (and future) younger learners, also requires further research on how plurilingual rhetorical communicative competences can be most effectively fostered for different types of learners, particularly with regards to the types of difficulties learner writers have, why they have them, and the relationships and nature of transfer (positive and negative) between plurilingual writers' communicative competences with different languages.

\section{Limitations and recommendations for future research}

The principal limitation on the present study was its relatively small-scale, including only 56 participants, all at the postgraduate level, within a single program (see Methodology). As indicated in the literature review (see Previous Work on L2 Academic and Rhetorical Writing), studies on university-level students' beliefs and practices concerning academic writing and their prior training on writing are lacking in Colombia, though they are also scarce even at an international level; most studies have examined students already involved in a writing instruction program. The results of the current study represent a preliminary step towards clarifying these matters, but clearly wider studies that include larger numbers of participants, particularly at the undergraduate level, from more institutions are required to gain a wider understanding of the issues. Such an understanding would be necessary as an evidential basis on which to develop approaches not only to better prepare current university-level students but also to reconsider the curricula of secondary- and indeed primary-level education on writing and rhetorical communication.

\section{Conclusion}

This preliminary study has shown that learning writers' own pre-existing beliefs about writing, academic writing, and rhetorical communication-especially when an additional language is involved-can create considerable challenges. Yet the abilities to not only produce effective rhetorical communication (including, but clearly not limited to, academic prose) but also critically interpret the rhetorical communication of others are increasingly crucial for academic and professional success in virtually every field of endeavor-as well as for effective democratic citizenship. For Colombia, as for many parts of the developing world (indeed the developed world as well), the value of developing such abilities amongst learners of all ages is perhaps still underappreciated. The challenges of developing effective approaches for training different kinds of learners in such abilities are likewise considerable. Nevertheless, it seems likely that success in these endeavors would provide current and future generations with powerful tools that support life-long success-and a clearer understanding of the underlying causes of learners' academic writing difficulties serves as a valuable first step towards this goal.

\section{References}

Ammon, U. (2007). Global scientific communication: Open questions and policy suggestions. AILA Review, 20(1), 123-133. http://dx.doi.org/10.1075/ aila.20.11 amm

Anderson, C. E., McDougald, J. S., \& Cuesta Medina, L. (2015). CLIL for young learners. In C. N. Giannikas, L. McLaughlin, G. Fanning, \& N. D. Muller (Eds.), Children learning English: From research to practice (pp. 137-151). Reading, UK: Garnet.

Anderson, L. W., Krathwohl, D. R., Airasian, P. W., Cruikshank, K. A., Mayer, R. E., Pintrich, P., Raths, J. \& Wittrock, M. (2001). A taxonomy for learning, teaching, and assessing: A revision of Bloom's taxonomy of educational objectives. Boston, MA: Allyn \& Bacon.

Arias Arias, V., \& Agudelo Montoya, C. L. (2010). ¿La lectura y la escritura de la universidad colombiana corresponde con el proyecto de la modernidad? Revista Latinoamericana de Estudios Educativos, 6(1), 95-109.

Armstrong, P. (2001). Science, enterprise and profit: Ideology in the knowledge-driven economy. Economy and Society, 30(4), 524-552. http://dx.doi. org/10.1080/03085140120089081 
Cuesta Medina, L., \& Anderson, C. E. (2014, September). Identifying self-regulatory problems in the context of academic writing amongst in postgraduate languageteacher trainees. Paper presented at the vi Coloquio Internacional sobre Investigación en Lenguas Extranjeras, Universidad Nacional de Colombia, Sede Bogotá, Bogotá, Colombia.

Badger, R., \& White, G. (2000). A process genre approach to teaching writing. ELT Journal, 54(2), 153-160. http://dx.doi.org/10.1093/elt/54.2.153

Bardi, M. (2015). Learning the practice of scholarly publication in English - A Romanian perspective. English for Specific Purposes, 37, 98-111. http://dx.doi. org/10.1016/j.esp.2014.08.002

Benfield, J. R. (2006). How authors can cope with the burden of English as an international language. CHEST Journal, 129(6), 1728. http://dx.doi.org/10.1378/ chest.129.6.1728

Bennett, K. (2010a). Academic discourse in Portugal: A whole different ballgame? Journal of English for Academic Purposes, 9(1), 21-32. http://dx.doi. org/10.1016/j.jeap.2009.11.002

Bennett, K. (2010b). Academic writing practices in Portugal: Survey of Humanities and Social Science researchers. Diacritica, 24(1), 193-209.

Berlin, J. A. (1984). Writing instruction in nineteenth-century American colleges. Carbondale, IL: Southern Illinois University Press.

Berlin, J. A. (1987). Rhetoric and reality: Writing instruction in American colleges, 1900-1985. Carbondale, IL: Southern Illinois University Press.

Biggam, J. (2008). Succeeding with your Master's dissertation: A step-by-step handbook. Maidenhead, UK: Open University Press.

Björk, L., Bräuer, G., Rienecker, L., \& Jöorgensen, P. S. (Eds.) (2003). Teaching academic writing in European higher education. New York: Kluwer Academic Publishers.

Bloom, B. S., Engelhart, M. D., Furst, E. J., Hill, W. H., \& Krathwohl, D. R. (1956). Taxonomy of educational objectives: The classification of educational goals, Handbook I: Cognitive domain. New York, NY: Longmans, Green.

Burgess, S., \& Martín-Martín, P. (Eds.) (2008). English as an additional language in research publication and communication. Bern, Switzerland: Peter Lang.

Burrough-Boenisch, J. (2006). Negotiable acceptability: Reflections on the interactions between language professionals in Europe and NNS 1 scientists wishing to publish in English. Current Issues in Language Planning, 7(1), 31-43. http://dx.doi. org/10.2167/cilp086.0

Bushnell, D., \& Hudson, R. A. (2010). The society and its environment. In R. A. Hudson (Ed.), Colombia: A country study (5th ed.). Washington, DC: Federal Research Division, Library of Congress.

Camargo Martínez, Z., Uribe Álvarez, G., Caro Lopera, M. Á., \& Castrillón, C. A. (2008). Estado del arte de las concepciones sobre prácticas de lectura y escritura en la universidad colombiana. Quindío, Colombia: Grupo de Investigación en Didáctica de la Lengua Materna y la Literatura, Universidad del Quindío.

Cárdenas, M. L. (2003). Teacher researchers as writers: A way to sharing findings. Colombian Applied Linguistics Journal, 5, 49-64.

Cárdenas, M. L. (2014). Publishing and academic writing: Experiences of authors who have published in PROFILE. PROFILE: Issues in Teachers' Professional Development, 16(2), 11-20.

Carlaw, K., Oxley, L., Walker, P., Thorns, D., \& Nuth, M. (2006). Beyond the hype: Intellectual property and the knowledge society/knowledge economy.Journal of Economic Surveys, 20(4), 633-690. http://dx.doi. org/10.1111/j.1467-6419.2006.00262.x

Casanave, C. P. (2008). "The stigmatizing effect of Goffman's stigma label: A response to John Flowerdew." Journal of English for Academic Purposes, 7(4), 264-267. http://dx.doi.org/10.1016/j.jeap.2008.10.013

Casanave, C. P., \& Hubbard, P. (1992). The writing assignments and writing problems of doctoral students: Faculty perceptions, pedagogical issues, and needed research. English for Specific Purposes, 11(1), 33-49. http://dx.doi. org/10.1016/0889-4906(92)90005-U

Castañeda, H. (2012). Profiling academic research on discourse studies and second language learning. $\mathrm{Co}$ lombian Applied Linguistics Journal, 14(1), 9-27.

Chala Bejarano, P. A., \& Chapetón, C. M. (2013). The role of genre-based activities in the writing of argumentative essays in EFL. PROFILE: Issues in Teachers' Professional Development, 15(2), 127-147.

Chambliss, D. F., \& Schutt, R. K. (2012). Making sense of the social world: Methods of investigation (4th ed.). Thousand Oaks, CA: SAGE Publications.

Chazal, E. de., \& Aldous, Y. K. (2006). From Japanese to Anglo-Saxon academic writing culture: A practical framework and a personal journey. The East Asian Learner, 2(2). 
Coffin, C., Curry, M. J., Goodman, S., Hewings, A., Lillis, T. M., \& Swann, J. (2003). Teaching academic writing: A toolkit for higher education. London: Routledge.

Colmenares, S. (2013). Prácticas de escritura académica en una universidad pública colombiana: Autoría, audiencia e interacción con otras voces. Lenguaje, 41(1), 201-227.

Cooper, A., \& Bikowski, D. (2007). Writing at the graduate level: What tasks do professors actually require? Journal of English for Academic Purposes, 6(3), 206221. http://dx.doi.org/10.1016/j.jeap.2007.09.008

Corbin, J., \& Strauss, A. (2008). Basics of qualitative research: Techniques and procedures for developing grounded theory (3rd ed.). Thousand Oaks, CA: Sage.

Correa, D. (2010). Developing academic literacy and voice: Challenges faced by a mature ESL student and her instructors. PROFILE: Issues in Teachers' Professional Development, 12(1), 79-94.

Cowan, R., \& van de Paal, G. (2000). Innovation policy in a knowledge-based economy. Luxembourg, Luxembourg: European Commission, Enterprise Directorate General.

Crawford, T., Mora Pablo, I., Lengelign, M., \& Goodwin, D. (2013). From contrastive rhetoric towards perceptions of identity: Written academic English in central Mexico. Colombian Applied Linguistics Journal, 15(1), 9-24.

Creswell, J. W. (2012). Educational research: Planning, conducting, and evaluating quantitative and qualitative research ( $4^{\text {th }}$ ed.). Boston, MA: Pearson.

Creswell, J. W., \& Plano Clark, V. L. (2011). Designing and conducting mixed methods research ( $2 \mathrm{nd} \mathrm{ed}$.). Thousand Oaks, CA: Sage.

Cummins, J. (2008). BICS and CALP: Empirical and theoretical status of the distinction. In B. Street \& N. H. Hornberger (Eds.), Encyclopedia of language and education ( $2^{\text {nd }}$ ed., Vol. 2, pp. 71-83). New York, NY: Springer.

Cummins, J., Brown, K., \& Sayers, D. (2007). Literacy, technology, and diversity: Teaching for success in changing times. Boston, MA: Allyn \& Bacon.

Cummins, J., \& Man Yee-fun, E. (2007). Academic language: What is it and how do we acquire It? In J. Cummins \& C. Davison (Eds.), International handbook of English language teaching. Boston, MA: Springer US. http://dx.doi.org/10.1007/978-0-387-46301-8

Curry, M. J. (2011, March). "Where there is no laundry": A review of books on writing for publication. Jour- nal of English for Academic Purposes. http://dx.doi. org/10.1016/j.jeap.2010.09.003

Curry, M. J., \& Lillis, T. M. (2004). Multilingual scholars and the imperative to publish in English: Negotiating interests, demands, and rewards. TESOL Quarterly, 38(4), 663. http://dx.doi.org/10.2307/3588284

David, P. A., \& Foray, D. (2002). An introduction to the economy of the knowledge society. International Social Science Journal, 54(171), 9-23. http://dx.doi. org/10.1111/1468-2451.00355

Diab, R. L. (2005). Teachers' and students' beliefs about responding to ESL writing: A case study. TESL Canada, 23(1), 28-43.

Díaz Hormazábal, R. (2007). Argumentative writing strategies and perceptions of writing in academia by EFL college students. Literatura y Lingüistica, (18), 253-282. http://dx.doi.org/10.4067/ S0716-58112007000100015

Douglas, W. W. (1976). Rhetoric for the meritocracy: The creation of composition at Harvard. In R. M. Ohlmann \& W. W. Douglas (Eds.), English in America: A radical view of the profession (pp. 97-132). Oxford, England: Oxford University Press.

Drucker, P. F. (1992). The age of discontinuity: Guidelines to our changing society (2nd ed.). New Brunswick, NJ: Transaction.

Duszak, A., \& Lewkowicz, J. (2008). Publishing academic texts in English: A Polish perspective. Journal of English for Academic Purposes, 7(2), 108-120. http://dx.doi.org/10.1016/j.jeap.2008.03.001

Eisenstein, E. (1979). The printing press as an agent of change: Communications and cultural transformations in Early-Modern Europe (Vol. 1). Cambridge, England: Cambridge University Press.

Escobar Alméciga, W. Y., \& Evans, R. (2014). Mentor texts and the coding of academic writing structures: A functional approach. HOW: A Colombian Journal for Teachers of English, 21(2), 94-111.

Evans, S., \& Green, C. (2007). Why EAP is necessary: A survey of Hong Kong tertiary students. Journal of English for Academic Purposes, 6(1), 3-17. http:// dx.doi.org/10.1016/j.jeap.2006.11.005

Ferguson, G. R., Pérez-Llantada, C., \& Plo, R. (2011). English as an international language of scientific publication: A study of attitudes. World Englishes, 30(1), 41-59. http://dx.doi. org/10.1111/j.1467-971X.2010.01656.x 
Fernández Polo, F. J., \& Cal Varela, M. (2009). English for research purposes at the University of Santiago de Compostela: A survey. Journal of English for Academic Purposes, 8(3), 152-164. http://dx.doi. org/10.1016/j.jeap.2009.05.003

Flower, L. S., \& Hayes, J. R. (1981). A cognitive process theory of writing. College Composition and Communication, 32(4), 365. http://dx.doi. org/10.2307/356600

Flowerdew, J. (1999a). Problems in writing for scholarly publication in English: The case of Hong Kong. Journal of Second Language Writing, 8(3), 243-264. http:// dx.doi.org/10.1016/S1060-3743(99)80116-7

Flowerdew, J. (1999b). Writing for scholarly publication in English: The case of Hong Kong. Journal of Second Language Writing, 8(2), 123-145. http://dx.doi. org/10.1016/S1060-3743(99)80125-8

Flowerdew, J. (2008). Scholarly writers who use English as an additional language: What can Goffman's "Stigma" tell us? Journal of English for Academic Purposes, 7(2), 77-86. http://dx.doi.org/10.1016/j. jeap.2008.03.002

Flowerdew, J. (2009). Goffman's stigma and EAL writers: The author responds to Casanave. Journal of English for Academic Purposes, 8(1), 69-72. http://dx.doi. org/10.1016/j.jeap.2009.01.001

Freedman, S. W., Dyson, A. H., Flower, L., \& Chafe, W. (1987). Research in writing: Past, present and future. Berkeley, CA: Center for the Study of Writing. Retrieved from https://eric.ed.gov/?id=ED285205

Gárate, M., \& Melero, A. (2005). Teaching how to write argumentative texts at primary school. In G. Rijlaarsdam, H. van den Bergh, \& M. Couzijn (Eds.), Effective learning and teaching of writing: $A$ handbook of writing in education (2nd ed., pp. 323-337). Boston, MA: Kluwer Academic Publishers.

Gea-Valor, M.-L., Rey-Rocha, J., \& Moreno, A. I. (2014). Publishing research in the international context: An analysis of Spanish scholars' academic writing needs in the social sciences. English for Specific Purposes, 36, 47-59. http://dx.doi.org/10.1016/j. esp.2014.05.001

Gómez, J. D. (2011). Teaching EFL academic writing in Colombia: Reflections in contrastive rhetoric. PROFILE: Issues in Teachers' Professional Development, 13(1), 205-213.

González Pinzón, B. Y., \& Vega, V. (2013). Lectura y escritura en la educación superior colombiana: Herencia y deconstrucción. Revista Interacción, 12, 195-201.
Goyes Morán, A., \& Klein, I. (2012). Alcances, limitaciones y retos en la enseñanza de la escritura en la universidad (Dos casos: Colombia y Argentina). In L. Laco, L. Natale, \& M. Ávila (Eds.), La lectura y la escritura en la formación académica, docente y profesional. Buenos Aires, Argentina: Editorial de la Universidad Tecnológica Nacional.

Graddol, D. (1997). The future of English? A guide to forecasting the popularity of the English language in the 21st century. London, England: The British Council.

Grant, D. M. (2010). Back to the future? Writing instruction in the 21 st century liberal arts. UNIversitas: The University of Northern Iowa Journal of Reseach, Scholarship, and Creative Activity, 6(2).

Hall, B. H., \& Mairesse, J. (2006). Empirical studies of innovation in the knowledge-driven economy. Economics of Innovation and New Technology, 15(4-5), 289-299. http://dx.doi.org/10.1080/10438590500512760

Hammann, L. (2005). Self-regulation in academic writing tasks. International Journal of Teaching and Learning in Higher Education, 17(1), 15-26.

Hanauer, D. I., \& Englander, K. (2011). Quantifying the burden of writing research articles in a second language: Data from Mexican scientists. Written Communication, 28(4), 403-416. http://dx.doi. org/10.1177/0741088311420056

Hillocks, G. J. (2011). Teaching argument writing, grades 6-12: Supporting claims with relevant evidence and clear reasoning. Portsmouth, $\mathrm{NH}$ : Heinemann.

Hinkel, E. (2007). Integrating the four skills: Current and historical perspectives. In R. B. Kaplan (Ed.), Oxford handbook in applied linguistics (2nd ed., pp. 110-126). Oxford, England: Oxford University Press.

Huang, J. C. (2010). Publishing and learning writing for publication in English: Perspectives of NNES PhD students in science. Journal of English for Academic Purposes, 9(1), 33-44. http://dx.doi.org/10.1016/j. jeap.2009.10.001

Huerta, M., Goodson, P., Beigi, M., \& Chlup, D. (2016). Graduate students as academic writers: Writing anxiety, self-efficacy and emotional intelligence. Higher Education Research \& Development, 1-14. http://dx.doi.org/10.1080/07294360.2016.12388 81

Hyland, K. (2016). Academic publishing and the myth of linguistic injustice. Journal of Second Language Writing, 31, 58-69. http://dx.doi.org/10.1016/j. jslw.2016.01.005 
Janssen, G., Nausa, R., \& Rico, C. (2012). Shaping the ESP curriculum of an English for PhD students program: A colombian case study of questionnaire research. Colombian Applied Linguistics Journal, 14(2), 51-69.

Jenkins, S., Jordan, M. K., \& Weiland, P. O. (1993). The role of writing in graduate engineering education: A survey of faculty beliefs and practices. English for Specific Purposes, 12(1), 51-67. http://dx.doi. org/10.1016/0889-4906(93)90027-L

Johns, A. (2003). Academic writing: A European perspective. Journal of Second Language Writing, 12(4), 313 316. http://dx.doi.org/10.1016/j.jslw.2003.08.005

Johnson, R. H. (2000). Manifest rationality: A pragmatic theory of argument. Mahwah, NJ: Erlbaum.

Kaplan, A. (1964). The conduct of inquiry: Methodology for behavioral science. San Francisco, CA: Chandler Publishing.

Kaplan, R. B., \& Baldauf, R. B. (2005). Editing contributed scholarly articles from a language management perspective. Journal of Second Language Writing, 14(1), 47-62. http://dx.doi.org/10.1016/j. jslw.2005.01.001

Kaufhold, K. (2015). Conventions in postgraduate academic writing: European students' negotiations of prior writing experience at an English speaking university. Journal of English for Academic Purposes, 20, 125-134. http://dx.doi.org/10.1016/j. jeap.2015.08.007

Kuteeva, M., \& Negretti, R. (2016). Graduate students' genre knowledge and perceived disciplinary practices: Creating a research space across disciplines. English for Specific Purposes, 41, 36-49. http://dx.doi. org/10.1016/j.esp.2015.08.004

Laco, L., Natale, L., \& Ávila, M. (Eds.) (2010). La lectura y la escritura en la formación académica, docente $y$ profesional. Buenos Aires, Argentina: Editorial de la Universidad Tecnológica Nacional.

Leki, I. C. (1994). Students' perceptions of EAP writing instruction and writing needs across the disciplines. TESOL Quarterly, 28(1), 81-101. http://dx.doi. org/10.2307/3587199

Li, Y., \& Flowerdew, J. (2009). International engagement versus local commitment: Hong Kong academics in the humanities and social sciences writing for publication. Journal of English for Academic Purposes, 8(4), 279-293. http://dx.doi.org/10.1016/j. jeap.2009.05.002

Lillis, T. M., \& Curry, M. J. (2006). Professional academic writing by multilingual scholars. Written
Communication, 23(1), 3-35. http://dx.doi. org/10.1177/0741088305283754

Lillis, T. M., \& Curry, M. J. (2010). Academic writing in a global context: The politics and practices of publishing in English. London, UK: Routledge.

Liu, L. (2005). Rhetorical education through writing instruction across cultures: A comparative analysis of select online instructional materials on argumentative writing. Journal of Second Language Writing, 14(1), 1-18. http://dx.doi.org/10.1016/j. jslw.2004.11.001

López-Navarro, I., Moreno, A. I., Quintanilla, M. Á., \& Rey-Rocha, J. (2015). Why do I publish research articles in English instead of my own language? Differences in Spanish researchers' motivations across scientific domains. Scientometrics, 103(3), 939-976. http://dx.doi.org/10.1007/s11192-015-1570-1

Lora González, R. F. (2010). La evaluacion de la escritura académica en situaciones de multiculturalidad: Un estudio de caso en la Universidad Nacional. Universidad Nacional de Colombia, Bogotá, Colombia.

MacDonald, S. P. (1994). Professional academic writing in the humanities and social sciences. Carbondale, IL: Southern Illinois University Press.

Maslow, A. H. (1966). The psychology of science: A reconnaissance. New York, NY: Harper \& Row.

Matsuda, P. K., Saenkhum, T., \& Accardi, S. (2013). Writing teachers' perceptions of the presence and needs of second language writers: An institutional case study. Journal of Second Language Writing, 22(1), 68-86. http://dx.doi.org/10.1016/j.jslw.2012.10.001

Migdalek, M. J., Rosemberg, C. R., \& Yáñez, C. S. (2014). La génesis de la argumentación: Un estudio con niños de 3 a 5 años en distintos contextos de juego. Íkala, 19(3), 251-267. http://dx.doi.org/10.17533/ udea.ikala.v19n3a03

Miller, C. R., \& Shepherd, D. (2004). Blogging as social action: A genre analysis of the weblog. In L. J. Gurak, S. Antonijevic, L. Johnson, C. Ratliff, \& J. Reyman (Eds.), Into the blogosphere: Rhetoric, community, and culture of weblogs. Minneapolis, MN: University of Minnesota.

Miller, T. P. (1997). The formation of college English: Rhetoric and belles lettres in the British cultural provinces. Pittsburgh, PA: University of Pittsburgh Press.

Mora González, C. A. (2014). The influence of graphic organizers in Al sixth graders' argumentative writing skill in an EFL context (Unpublished Master's thesis). Universidad de La Sabana, Chía, Colombia. 
Moreno, A. I., Rey-Rocha, J., Burgess, S., López-Navarro, I., \& Sachdev, I. (2012). Spanish researchers' perceived difficulty writing research articles for English-medium journals: The impact of proficiency in English versus publication experience. Ibérica: Revista de La ..., 24, 157-184.

Moya Pardo, C., Vanegas Sánchez, I., \& González González, C. (2014). Escribir hoy en el posgrado. Escritura académica y producción de conocimiento. Bogotá, Colombia: Universidad Externado de Colombia, Facultad de Ciencias de la Educación.

Muresan, L.-M., \& Pérez-Llantada, C. (2014). English for research publication and dissemination in bi-/ multiliterate environments: The case of Romanian academics. Journal of English for Academic Purposes, 13, 53-64. http://dx.doi.org/10.1016/j. jeap.2013.10.009

Nanwani, S. (2009). Linguistic challenges lived by university students in Bogotá in the development of academic literacy. Colombian Applied Linguistics Journal, 11, 136-148.

Narváez Cardona, E., Girón, S. L., Gómez, O. L., Méndez, F., Mosquera, J., Fernando, L., ... Ariza. (2009). Escritura académica en un programa de formación en epidemiología: Reflexiones sobre prácticas de enseñanza. Revista de La Maestría En Salud Pública, 7(13), 1-13.

Negretti, R., \& Kuteeva, M. (2011). Fostering metacognitive genre awareness in $\mathrm{L} 2$ academic reading and writing: A case study of pre-service English teachers. Journal of Second Language Writing, 20(2), 95-110. http://dx.doi.org/10.1016/j.jslw.2011.02.002

Nunan, D. (1989). Designing tasks for the communicative classroom. Cambridge, England: Cambridge University Press.

Nunan, D. (2001). Syllabus design. In M. Celce-Murcia (Ed.), Teaching English as a second or foreign language ( $3^{\text {rd }}$ ed., pp. 55-65). Boston, MA: Heinle \& Heinle.

Ortiz Casallas, E. M. (2011). La escritura académica universitaria: Estado del arte. Íkala, 16(28), 17-41.

Pascarella, E. T., Wolniak, G. C., Seifert, T. A., Cruce, T. M., \& Blaich, C. F. (2005). Liberal arts colleges and liberal arts education: New evidence on impacts. San Francisco, CA: Jossey-Bass.

Pérez-Llantada, C. (2015). Genres in the forefront, languages in the background: The scope of genre analysis in language-related scenarios. Journal of English for
Academic Purposes. http://dx.doi.org/10.1016/j. jeap.2015.05.005

Pérez-Llantada, C., Plo, R., \& Ferguson, G. R. (2011). “You don't say what you know, only what you can": The perceptions and practices of senior Spanish academics regarding research dissemination in English. English for Specific Purposes, 30(1), 18-30. http:// dx.doi.org/10.1016/j.esp.2010.05.001

Pérez Abril, M., \& Rincón Bonilla, G. (Eds.) (2013). ¿Para qué se lee y se escribe en la universidad colombiana? Un aporte a la consolidación de la cultura académica del pais. Bogotá, Colombia: Editorial Pontificia Universidad Javeriana.

Pittam, G., Elander, J., Lusher, J., Fox, P., \& Payne, N. (2009). Student beliefs and attitudes about authorial identity in academic writing. Studies in Higher Education, 34(2), 153-170. http://dx.doi. org/10.1080/03075070802528270.

Riazi, A. (1997). Acquiring disciplinary literacy: A social-cognitive analysis of text production and learning among Iranian graduate students of education. Journal of Second Language Writing, 6(2), 105-137. http://dx.doi.org/10.1016/ S1060-3743(97)90030-8

Rincón, G., \& Gil, J. S. (2010). Las prácticas de lecture y de escritura académicas en la Universidad del Valle: tendencias. Lenguaje, 38(2), 387-419.

Ripley, A. (2013). The smartest kids in the world: And how they got that way. New York, NY: Simon \& Schuster.

Russell, D. R. (2002). Writing in the academic disciplines: $A$ curricular history ( $2^{\text {nd }}$ ed.). Carbondale, IL: Southern Illinois University Press.

Sahlberg, P. (2011). The fourth way of Finland. Journal of Educational Change, 12(2), 173-185. http://dx.doi. org/10.1007/s10833-011-9157-y

Sahlberg, P. (2014). Finnish lessons 2.0: What can the world learn from educational change in Finland? ( $2^{\text {nd }}$ ed.). New York, NY: Teachers College Press.

Schroeder, C. (2001). Academic literacies, legitimacy crises, and electronic cultures. Journal of Literacy and Technology, 1(2).

Scott, R. L. (1967). On viewing rhetoric as epistemic. Central States Speech Journal, 18(1), 9-17. http://dx.doi. org/10.1080/10510976709362856

Seow, A. (2002). The writing process and process writing. (pp. 315-320). Cambridge, UK: Cambridge University Press. 
Shi, L., \& Cumming, A. (1995). Teachers' conceptions of second language writing instruction: Five case studies. Journal of Second Language Writing, 4(2), 87-111. http://dx.doi.org/10.1016/1060-3743(95)90002-0

Toulmin, S. E. (2003). The uses of argument (Updated.). Cambridge, England: Cambridge University Press.

Uzuner, S. (2008). Multilingual scholars' participation in core/global academic communities: A literature review. Journal of English for Academic Purposes, 7(4), 250-263. http://dx.doi.org/10.1016/j. jeap.2008.10.007

Viáfara González, J.J. (2008). From pre-school to university: Student-teachers' characterize their EFL writing development. Colombian Applied Linguistics Journal, 10,73-92. Retrieved from http://revistas.udistrital. edu.co/ojs/index.php/calj/article/view/98

\section{Appendix A: Questionnaire}

This short questionnaire collects information about your academic writing background. Your anonymity will be respected, and the answers you provide in this form will be used solely for educational and research purposes. It is expected that you would be able to complete the questionnaire in 15-25 minutes.

I understand and agree that my answers may be used for the purposes of research at [name of institution].

- Yes

- $\mathrm{No}$

1. What is your highest level of academic training? (primary, secondary, undergraduate, other professional degree, masters, doctoral)

- Primary

- Secondary

- Undergraduate

- Masters

- Doctoral

- Other professional degree
Wagner, T. (2008). The global achievement gap: Why even our best schools don't teach the new survival skills our children need - and what we can do. New York, NY: Basic Books.

Wagner, T. (2012). Creating innovators: The making of young people who will change the world. New York, NY: Scribner.

Wan, W. (2014). Constructing and developing ESL students' beliefs about writing through metaphor: An exploratory study. Journal of Second Language Writing, 23, 53-73. http://dx.doi.org/10.1016/j. jslw.2014.01.002

Yildirim, R., \& Ilin, G. (2009). Tutors' and students' perceptions of what makes a good undergraduate research paper. Procedia. Social and Behavioral Sciences, I(1), 1636-1640. http://dx.doi.org/10.1016/j. sbspro.2009.01.288

2. In what subject or subject area is your undergraduate/professionalor otherhigher academic degree(s)?

3. What is your first language (L1)?

- Spanish

- English

- Other

4. Did you receive training in writing in your L1?

- Yes

- No

5. If you received general training in writing in your L1, at what educational level did you receive it?

- Primary

- Secondary

- Undergraduate

- Masters

- Doctoral

- Other professional degree 
6. If you received general training in writing in your L1, did it cover any of the following aspects (check all options that apply):

- Orthography

- Grammar

- Punctuation

- Sentence structure

- Paragraph structure

- Essay structure

- Genres or types of writing (descriptive, expository, compare/contrast, cause/effect, reflective, summary, narrative, argumentative)

- Rhetoric persuasion

- Argumentation

7. Did you receive training in your L1 about critical reading?

- Yes

- No

8. Did you receive specific training in academic writing in your L1?

- Yes

- No

9. If you received specific training in academic writing in your L1, at what educational level did you receive it:

- Primary

- Secondary

- Undergraduate

- Masters

- Doctoral

- Other professional degree
10. If you received specific training in academic writing in your L1, was it through a specific academic writing course?

- Yes

- No

11. Did you receive specific training in your L1 in finding, analyzing, evaluating, and using information to support your writing?

- Yes

- No

If English is your L1, then skip questions 12 to 19.

12. Did you receive training in writing in English?

- Yes

- No

13. If you received general training in writing in English, at what educational level did you receive it?

- Primary

- Secondary

- Undergraduate

- Masters

- Doctoral

- Other professional degree

14. If you received general training in writing in English, did it cover any of the following aspects (check all options that apply)?

- Orthography

- Grammar

- Punctuation

- Sentence structure

- Paragraph structure

- Essay structure 
- Genres or types of writing (descriptive, expository, compare/contrast, cause/effect, reflective, summary, narrative, argumentative)

- Rhetoric persuasion

- Argumentation

15. Did you receive training in English about critical reading?

- Yes

- No

16. Did you receive specific training in academic writing in English?

- Yes

- No

17. If you received specific training in academic writing in English, at what educational level did you receive it?

48

- Primary

- Secondary

- Undergraduate

- Masters

- Doctoral

- Other professional degree

18. If you received specific training in academic writing in English, was it through a specific academic writing course?

- Yes

- No

19. Did you receive specific training in English in finding, analyzing, evaluating, and using information to support your writing?

- Yes

- $\mathrm{No}$
20 . Based on your experience, rank what you consider the most important features of academic writing. (Scale ranges from 1 to 7 , being 1 the least important, and 7 the most important.)

_ Orthography

_ Grammar

_ Sentence structure

_ Paragraph structure

_ Essay structure

_ Evidence

Persuasiveness

21 . Briefly describe why you choose your first and second rankeditems as the most important features.

22. Briefly describe why you choose your sixth and seventh ranked items as the least important features.

23. Briefly describe how you usually find and/or use information to support your writing in your L1.

24. What have you done, if anything, to solve any difficulties you have encountered in academic writing in your L1?

If English is your L1, then skip questions 25-29.

25. If English is not your L1, briefly describe how you usually find and/or use information to support your writing in English.

26. If English is not your L1, briefly describe what you find most difficult about academic writing in English.

27. What have you done, if anything, to solve any difficulties you have encountered in academic writing in English (if English is not your L1)? 
28. If English is not your L1, briefly describe the most important differences between any training you received in writing in your L1 and any training you received in writing in English.
29. If English is not your L1, briefly describe the most important differences you see in the way your write in your L1 and in English.

\section{Appendix B : Semi-Structured Interview Guide Questions}

This semi-structured interview inquiries about your academic writing beliefs and your practices when writing texts for academic purposes. Your anonymity will be respected, and the answers you provide in this form will be used solely for educational and research purposes. It is expected that the interview will take no longer than 20-25 minutes.

Interviewer's name:

Interviewee's name:

I understand and agree that my answers may be used for the purposes of research at [name of institution].

- Yes

- No

1. Do you find academic writing in English difficult? (Yes/No.)

2. (If the respondent says YES to Question 1, ensure you ask Questions 2 and 3; otherwise, skip them).

3. Briefly describe what you find most difficult about academic writing in English.

4. What have you done, if anything, to solve any difficulties you have encountered in academic writing in English?

5. Describe the most important differences you see in the way your write academic texts in your L1 and in English.

6. What kind of resources do you use to produce academic texts in English?

7. What proves effective when you write academic texts in English?

8. What would you need to improve your academic writing competence?

9. Are there any additional comments you would like to make?

How to reference this article: Anderson, C. E. and Cuesta-Medina, L. (2018). Beliefs and Practices Concerning Academic Writing among Postgraduate Language-Teacher Trainees. Íkala, Revista de Lenguaje y Cultura, 24(1), 29-49. DoI: 10.17533/udea.ikala.v24n01a01 